\title{
Reflecting on Personal Routines to New Ways of Teaching by German Geography Teachers: Effects of a Teacher Training Project in North Rhine-Westphalia
}

\author{
Maxim Krohmer ${ }^{1, *} \&$ Alexandra Budke ${ }^{2}$ \\ ${ }^{1}$ Departement of Geography, Bonn University, Bonn (North Rhine-Westphalia), Germany \\ ${ }^{2}$ Institute of Geography Education, University of Cologne (North Rhine-Westphalia), Germany \\ *Correspondence: Departement of Geography, Bonn University, Bonn (North Rhine-Westphalia), Germany, \\ Meckenheimer Allee 166, D-53115. Tel: 49-228-73-3527. E-mail: mkrohmer@uni-bonn.de
}

Received: October 6, $2020 \quad$ Accepted: October 26, 2020 Online Published: November 12, 2020

doi:10.5430/jct.v9n4p55

URL: https://doi.org/10.5430/jct.v9n4p55

\begin{abstract}
The gap between educational knowledge that is taught in universities and actions by teachers can be sizeable. A sustainable change in teachers' efforts requires particular sensitivity and awareness of this gap between subject-specific educational thinking and acting and between theory and practice. This study explored the extent to which a reflection on personal routine in class undertaken by geography teachers, and the associated awareness of their deficits ("the gap"), can contribute to a change in action. In this study, ten teachers from German Gymnasiums in North Rhine-Westphalia participated in a four-month-long intervention. The teachers had to document their lessons, work through possible deficits in peer discussions, and discuss solutions. The results showed that although intervention helped raise awareness of deficits, it was not enough to bring about a lasting change in teachers' actions. Possible causes for this lack of lasting change are reflected upon, and teacher training consequences are considered.
\end{abstract}

Keywords: teacher-training, geography education research, reflection, routines, innovation

\section{Introduction}

Teachers are seldom taught to use existing educational knowledge concerning subject-specific approaches of good teaching (Konrad, 2005). When the complexity and connectivity of expertise in geography lessons and a need for action are increasing, it is becoming more challenging to translate knowledge into action, so much so that it falls behind or even becomes contradictory to knowledge (Konrad, 2005). Many studies describe and analyze concepts and approaches of innovative school development and teaching methods (Schreiner et al., 2019; Fögele, Mehren, \& Rempfler, 2020). They report on empirical research, experiences, and visions for the realization of new teaching methods. The decisive factor for implementing innovations on a micro level, i.e., innovations that affect the classroom and individual lessons, are teachers and their interaction with students (Krohmer \& Budke, 2018). In this context, teachers' routines could be identified as precursors or prerequisites for innovations in classroom activities and decisive obstacles (Krohmer \& Budke, 2019, in press). On the one hand, innovation is only perceived as such if an old routine had been broken. On the other hand, highly practiced routines are a barrier to innovation in teaching.

However, do teachers know about their routines, and do they reflect on them? In everyday life, professionally experienced teachers see themselves as practitioners who justify their actions through rich experience (Haas, 1993, p. 5). Practitioners develop their subjective educational theory as the "official" education gained when entering the profession is perceived to be not entirely useful. Furthermore, many teachers consider that educational theory contributes little or nothing to the development of "survival strategies "in an everyday school environment.

As a teacher progresses through their career professional (geography), educational knowledge fades into the background, and experience-based knowledge may become relevant for everyday action (Haas, 2005). As a result, personal, educational theories are rarely questioned and planning as well as execution of lessons are not subject to control. Likely, feedback is rarely given to teachers due to a lack of regular supervision in many German schools. Consequently, suboptimal routines, which are not based on professional educational knowledge and do not 
contribute to students' development, may be formed (ibid. page 15).

Professional knowledge that teachers develop through their professional careers remains behind its potential (ibid. p. 15). Nevertheless, would knowledge about routines help to initiate new action? We think so! We believe it is necessary to reflect on routines in geography lessons to innovate personal teaching, in short, REROGLIT. Our intervention involved German Gymnasium teachers in North Rhine-Westphalia and consisted of three main parts: a documentation phase in which the participating teachers documented their lessons independently; a weekly review in which the teachers received a short evaluation of their documentation to highlight possible routines and; tandem conversations in which the teachers could exchange their experiences and discuss and advise possible strategies for solving problems in their teaching.

Previous studies have explored patterns of perception and assessment of geography teachers' educational innovations (Krohmer \& Budke, 2018) and recurring routines of geography lessons as a prerequisite for these innovations. This study aims to combine and develop these findings. Accordingly, the study seeks to create opportunities for reflection on personal teaching to enable geography teachers to acquire new knowledge about their teaching and, if necessary, to adopt new, innovative actions. We want to reach these goals through REROGLIT, with the central questions of this study being:

- How does REROGLIT contribute to a reflection on teaching and changes in geography teachers' teaching routines?

-Which part of REROGLIT contributes to reflection and a subsequent change of routines?

- In what way do teachers perceive and evaluate individual opportunities for reflection using REROGLIT?

\section{Theoretical Framework}

The following section is divided into two parts: the first explaining the gap between subject-specific educational knowledge and action of geography teachers in the classroom based on (meta)cognitive psychological principles and subjective theories (chapter 3.1 and 3.2); the second focusing on the theoretical cornerstones of the intervention tool REROGLIT and its proposed use to bridge the gap (chapter 3.3).

\subsection{The Use and the Lethargy of Knowledge}

The question of how knowledge is constructed and used is of particular importance for cognitive psychology. The knowledge referred to here is geographic educational knowledge acquired during a teacher's education. This subject-specific (geographical) knowledge can be broken down into knowledge about teaching and learning within and outside of school, selection, legitimation and educational reconstruction of learning objects, definition, and justification of teaching objectives, methodological structuring of learning processes, and the appropriate consideration of psychological and social starting conditions of teachers and learners (KVFF, 1998, p. 14). In Germany, subject-related educational knowledge is a central part of the teacher qualification at university (five-year master's degree) and is further deepened and transferred during the 18-month apprenticeship at a school. Developing such a (geographic educational) knowledge aims to make knowledge applicable, enable knowledge to be followed by decisions, and be merged into observable actions (Konrad, 2005, p. 40). For geography teachers, the transfer of educational knowledge into visible classroom results is crucial for good teaching success. In particular, it is not the pure possession of knowledge but the intelligent and targeted application of existing knowledge that is important. This includes the effective fostering of geographical competencies, evidence-based information on the learning effectiveness of media and methods, and the consideration of students' everyday perceptions when dealing with subject topics. If teachers do not use available (geographic) educational knowledge, then scientific findings may never be used in their targeted environment, resulting in the further development of teaching overall unable to take place. Furthermore, utilizing knowledge is a vital prerequisite for innovation since only new ideas used in some form are innovations.

In this context, the significance of routines must be highlighted. In previous studies, we focused on the perception and evaluation of educational innovations in geography teaching. We identified that routines, such as structuring a lesson in clear phases and using various methods, are particularly crucial for innovations in geography teachers' teaching (Krohmer \& Budke, 2018). Only routines would provide sufficient freedom for reflection, and the opportunity to change general methods used as innovations can only be achieved by breaking routines. Besides, we made observations of routines in geography teaching, where we identified geography-specific patterns of routines based on scientific research and findings (Krohmer \& Budke, publication pending). Thus, although 
geography-specific educational knowledge may exist in geography teachers, it may not be accessed in busy everyday school life. A vivid expression of this problem is the concept of inert knowledge (Renkl, 1994), which refers to the phenomenon that people are often not able to apply the knowledge acquired in institutionalized teaching-learning processes to new situations or changed circumstances (Konrad, 2005; Whitehead, 1929; Renk1, 2001; Mandl et al., 1993). Concerning geography teachers, theoretical knowledge about principles of geography education, such as multiperspectivity (Rhode-Jüchtern, 2013) and topicality/future orientation (Haversath 2013; Hicks \& Holden, 2007) or problem orientation (Felzmann, 2013) may be available but may not be being applied in teaching practice. Consequently, it seems worthwhile to investigate which factors are responsible for knowledge not being used optimally and ask how the potential "lethargy of knowledge" be explained?

\subsection{The Gap between Knowledge and Action}

A possible explanation for the problem of inert knowledge can be found in a deficit of metacognitions. Metacognitions can be classified into three different categories, according to Flavell (1997, p. 906ff); Metacognitive knowledge (metacognitive awareness), metacognitive regulation (metacognitive monitoring and self-regulation), and metacognitive experiences (metacognitive feelings and judgments). Metacognitive knowledge refers to knowledge about learning (Wenden, 1998) and is considered relatively stable information learners have about their cognitive processes and others (Flavell \& Wellman, 1977). This knowledge is stable, so learners can become conscious of it and articulate what they know. Metacognitive regulation is the general skills through which learners manage, direct, regulate, and guide their learning, i.e., planning, monitoring, and evaluating. Metacognitive experience is the learner's awareness that the learning process is not progressing well, or fluently, or has failed, which is also described as the feeling of knowledge or confidence (Efklides, 2009). If one of these components is deficient, the transition from actual knowledge to an action cannot occur. For example, if a geography teacher lacks knowledge of the relevant input on argumentation processes (Budke, 2012) or the conditions of applying concept maps in geography class (Fögele, Mehren, \& Rempfler, 2020), metacognitive control, in the form of target-oriented use of these methods in the classroom, cannot take place and a subsequent action does not occur.

In addition to these metacognitions, subjective theories of geography teachers must also receive attention as: "Pedagogical experts seem to orient themselves more towards their subjective theories and less towards scientific training content, with the faster they had to act and the more emotionally charged they were in the process also being influential" (Wahl, 1991, p. 5). Subjective theories of teachers are based on biographical experience acquired during their school years or university education, which ranges from the understanding of the subject, experiences with former role models, political views, personal daily form, general health, and job satisfaction (Budke, 2010). Besides, the teacher's interests, attitudes, and educational and professional knowledge are incorporated into the lessons' planning and design. Concerning geography lessons, teachers' subjective theories represent complex aggregates of conscious and unconscious beliefs on fundamental questions and ideas about geography, such as an emphasis on spatial orientation, the application of spatial concepts at different scales, or the focus on process and systems thinking (Rempfler, 2018). Thus, subjective theories form the basis for interpreting situations and planning of action and ultimately determine the implementation of (new) actions. Connections to the fostering of metacognitions are evident when regarding the modification of subjective theories. Both approaches are based on a long-term learning process, which is characterized by conscious and reflective interventions. As shown by numerous research studies, action-supporting strategies can be taught and practiced by reflecting on personal learning, identifying personal deficits, or by activating background knowledge, for example (Schraw, 2001; Gage \& Berliner, 1996; Reinfried, 2007; Fögele \& Mehren, 2015a).

\subsection{An Attempt to Bridging the Gap with REROGLIT}

Teachers, particularly those with a long professional experience, see themselves as practitioners who justify their actions solely through rich experience (Haas, 1993, p. 46). Educational knowledge is only applied at certain times; Meyer (2014) speaks in this context sarcastically of holiday education. Everyday lesson planning and realization are not always based on normative, goal-oriented learning models (Haas, 1998; Wittrock, 1986). These practitioners often develop their subjective theories, which are rarely questioned because they usually teach alone as group consultation, and reflection is rare in German schools. However, raising awareness of these theories by triggering the teacher's dissatisfaction, for example, can help determine how these teachers can improve their performance. The basic idea behind modifying everyday theories and fostering metacognition is to modify bundled and solidified structures, such as personal routines, through reflection to be consciously processed and evaluated by the teacher. Once this is done, these theories can be treated further, such as restructuring in a self-directed and conscious learning process. The aim is to change previous action-controlling processes and structures per newly received information 
while establishing new action-controlling processes and structures to determine future action.

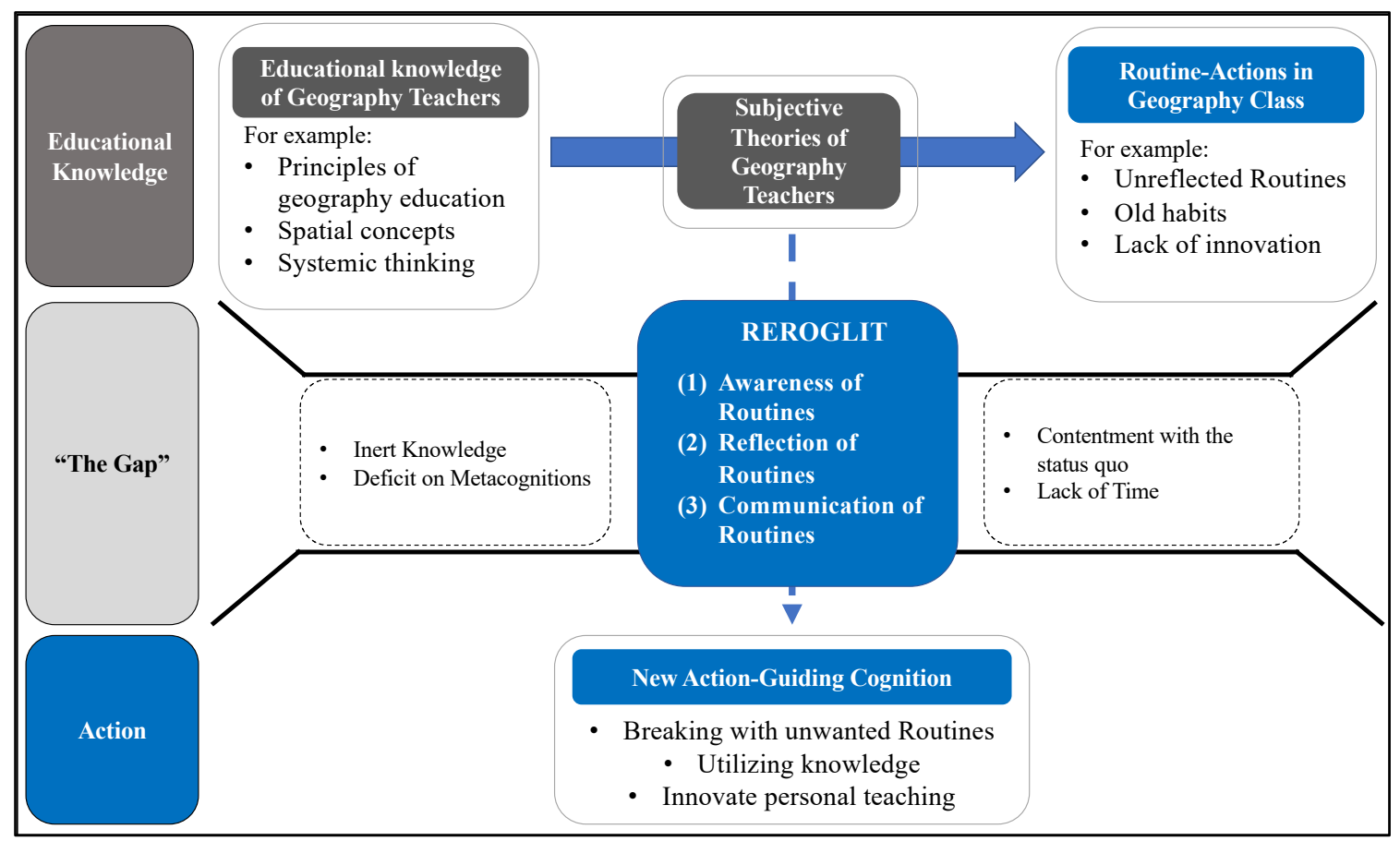

Figure 1. From Knowledge to New Action-Guiding Cognitions

Figure 1 shows that the educational knowledge taught at university and during teachers' actions is highly influenced by their subjective theories, so their everyday teaching is often characterized by routine action, old behavior, and a possible lack of innovation. To use the existing educational knowledge to break routines, it is necessary to reorganize, change, or configure subjective theories so that dissatisfaction with the status quo or activation of the inert knowledge is initiated. Here our intervention REROGLIT (reflection on routines in geography lessons to innovate teaching) functions as a bridge by supporting teachers in recognizing and evaluating their old action patterns and reorganizing them to develop their teaching by forming new action-guiding cognitions. With our intervention REROGLIT, we aim to uncover, reflect, question, and, if necessary, change established and unreflected routines of geography teachers in order to innovate personal teaching and thus "bridge the gap" between knowledge and action.

\subsubsection{Awareness of Routines with REROGLIT}

Based on the considerations outlined by Wahl (2001) on the change of subjective theories and routines, the theoretical and practical cornerstones of our intervention REROGLIT consists of (1) raising awareness of routines, (2) reflection on routines, and (3) communication of routines (see figure 1). The relearning of strongly established subjective theories and routines requires a mixture of awareness and confrontation with one's current routines. The intention is to ensure that explicit educational knowledge is not isolated and becomes useless (tacit knowledge cf. 3.1) for new actions. Therefore, through confrontation with one's current routines, a process of awareness must be set in motion that links condensed and unwanted routines with existing knowledge in order to override them in the process of relearning. Unwanted routines can only be reduced to such an extent through repetition, where they can then be used in everyday life to regulate actions (Wahl, 1995, Renate Schwarz-Govaers, 2008, p. 32).

Consequently, in this study, we aimed to make geography teachers aware of general educational and geography-specific principles. Using principles of general education, such as classroom management (Haubrich, 2006, p. $283 \mathrm{ff}$ ) or of student-oriented methods and media (Helmke, 2012), we tried to make teachers aware of the visual structure of their teaching, such as the overall organization of teaching (according to Seidel, Shavelson 2007; Baumert et al., 2010; Kunter \& Trautwein, 2013; Köller, 2014). The geography educational principles that we focus on in the intervention are problem orientation (Felzmann, 2013), the principle of multiperspectivity (Rhode-Jüchtern, 2013), the principle of actuality and future orientation, and the topicality principle (Haversath, 2013; Hicks \& Holden, 2007). This selection was made based on current empirical findings on the perception and understanding of effective 
geography teaching by professors, subject leaders, and teachers (Rempfler, 2018). Furthermore, we also aim to raise awareness of the deep structure of teaching, i.e., the awareness of teacher-student interaction, instruction quality, student-orientation, and competence-orientation. We achieve this by raising awareness of classroom management and the constructive support within teaching phases (Seidel \& Shavelson, 2007; Baumert et al., 2010; Kunter \& Trautwein, 2013; Köller, 2014), and thorough evaluation of the deep structure of the lesson by the teachers with the methods described in 4.1.1.

\subsubsection{Reflection of Routines with REROGLIT}

The process of relearning and breaking unwanted, ineffective routines is primarily achieved through reflective thinking. Reflection involves maintaining a critical distance from an individual's thinking, knowledge, skills, and actions by changing perspectives, with the aim of conscious and responsible self-control (Häcker \& Rihm, 2005, p. 362). The intention is to ensure that established unwanted routines are "liquefied," but at some point also "solidified" again within new wanted routines (Meyer et al., 2007). However, to do this, teachers need to be aware of their routines, be willing to reflect critically and, if necessary, modify, abandon and/or restructure these old routines (Linsner, 2009, p 61). Experience has shown that individuals on their own are usually overburdened with these tasks. This starts with identifying that an individual's behavior requires change, as often the distance to one's behavioral problem is not present. Even if this stage is successful and possible solutions have been developed, further obstacles arise depending on personal disposition or concrete working conditions. Uncertainty about the reaction of interaction partners (participants, colleagues, superiors) to new behavior patterns and fear of possible negative experiences can paralyze change initiatives (Krohmer \& Budke, 2018).

\subsubsection{Communication of Routines}

Through REROGLIT, we provide a collegial network in which teachers found support by discussing routines in small groups based on documentation of personal teaching and reflection (Wahl, 2006; Schmidt, 2001; 2005). New educational insights and reflection can be gained through this exchange, and have the chance of becoming effective in terms of behavior to replace previous unwanted routines after merging with this previous confronted knowledge. A positive effect of working in such small groups to change unwanted routines and the development of problem-solving strategies can be explained by the social support approach, which states that burdens and stressful situations are better managed when a person "is integrated into a network of well-functioning social relationships, experiences, and emotional exchange, and is sure of potential help" (Franz, 1985, p. 80f.). Also, other studies have shown that the help of colleagues (and superiors) is much more effective in the case of burnout or in coping with new professional tasks than, for example, that of the life partner or other family members (Constable \& Russel, 1986, LaRocco \& Jones, 1978).

\section{Methodology}

A large number of studies suggest that a systematic transfer of knowledge and skills in short-term, one-time educational events only leads to a (temporary) gain of competence (Konrad, 2005; Koschmann et al., 1996, Renkl et al., 1994, Lude, 2001). Therefore, we decided to structure our intervention over four months, offering teachers various opportunities to reflect on their teaching and uncover possible teaching changes over time in a mixed-methods design (Kuckartz, 2014). A total of 10 teachers took part in this intervention. The selection was made based on sampling by self-activation (Reinders, 2005). Thus, the selection of the participating teachers depended on their willingness to join the study. For this purpose, schools in the region of North Rhine-Westphalia were contacted. The aim was to get teachers with various routines, which are already experienced in the teaching profession and are therefore considered practitioners (cf. 3.3). All participants were teachers (6 women and four men) from different German Gymnasiums in North Rhine-Westphalia and have different teaching experiences ranging from 3 to 15 years of active apprenticeship in geography teaching.

\subsection{Research Design}

To answer the question of the extent to which REROGLIT leads to an increased reflection of teaching and potential changes in personal routines, we decided to use a mixed-method approach (Kuckartz, 2014) where we worked with both qualitative and quantitative survey methods. The methodological structure is summarized in Figure 2 and the subsequent chapters, with each survey method dealt with individually through a description of their aim and methodological realization. 


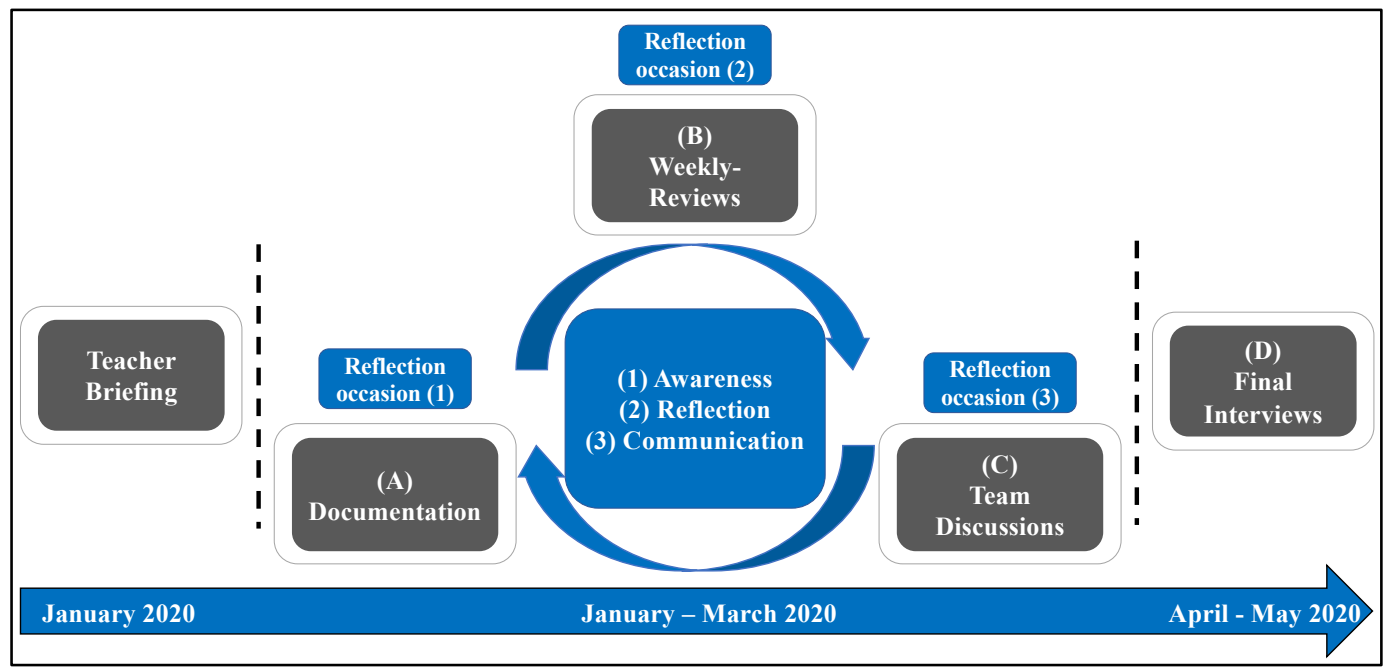

Figure 2. Methodical Structure and Temporal Sequence of REROGLIT (Own Illustration)

The intervention technique REROGLIT consisted of three main components: (A) Documentation; (B) Weekly Reviews, and; (C) Team Discussions. These were designed to repeat themselves in a continuous process over time, allowing for different occasions of reflection (1-3). These occasions were based on three theoretical compounds of (1) Awareness, (2) Reflection, and (3) Communication described in section 2.3.1 to 2.3.3. Before starting the intervention, teachers were informed about what they would be facing in the coming weeks and months in a detailed briefing. At the end of the intervention, interviews were conducted with each participant. This methodological selection aimed to evaluate the effect of the intervention REROGLIT as a whole and the individual components. Further, it was interesting to find out how the occasions for reflection were perceived by the teachers and which one contributed to their reflection and change in routines used in their geography lessons.

\subsubsection{Documentation}

The Documentation was a self-created survey tool that allowed teachers to record and evaluate their lessons, thus contributing to the awareness of routines (cf. 2.3.1). The Documentation aimed to enable teachers to recognize their action patterns through recording their teaching actions in class, to evaluate themselves, and, if necessary, to initiate changes. We wanted to achieve this by supporting teachers to recognize problems and deficits in their teaching and thus create dissatisfaction in their current teaching style and compare (geographic) educational theory with the recorded teacher actions. Moreover, we wanted to use the Documentation to highlight the extent to which development or change within recording can be observed through the course of the study, and the action patterns the whole group exhibit, and how the awareness of personal actions was evaluated. For this purpose, we worked with LimeSurvey, a free online application that enabled us to develop online surveys and record our results. With this application, we created an online survey for the participants that could be used to document every lesson they taught. Methodologically we followed the tradition of the "teacher-as-researcher" movement (Stenhouse, 1975), where teachers observe and reflect their actions on a scientific basis and through action research (Altrichter \& Posch, 2007) where teachers actively participate in the research process. The structure of the Documentation primarily consisted of three sections: "Lesson organization,"; "Principles of geography education," and; "Evaluation of the deep structure", and were based on the theoretical explanations in 2.3.1.

Concerning "Lesson organization", the main focus was on recording the lesson's time structure, the used methods and media, and the individual actions of the teacher, as well as their satisfaction with their teaching phases. "Lesson organization" was based on findings from previous studies that focused on the identification of recurring situations in geography classrooms (Krohmer \& Budke, 2019 publication pending) and on the theoretical base of the visual structure of teaching (Baumer, 2010; Kunter \& Trautwein 2013) to recognize patterns of personal teaching, such as the duration of the different teaching phases, the methods and media used, and the satisfaction with their implementation. By incorporating the recording of "Principles of geography education", such as the principles of problem orientation, topicality, and multi-perspectivity, we aimed hand to uncover deficits in the teaching activities of the participants on the one and to activate existing knowledge through the specification of these principles in the 
Documentation on the other hand (Maier \& Budke, 2018). This decision was supported by theoretical explanations of explicit knowledge's connection to unwanted routines such as those described in Chapter 2.3. The following items were to be documented for the problem orientation principle: "Problematization", "Problem Identification", "Hypothesizing", "Processing Sequence", "Hypothesis Testing", and "Reflection of the Solution". This sequence of items corresponds chronologically to the common problem-oriented geography lessons teachers learn during their academic education (see Felzmann, 2013). "Problematization" means the lesson has a leading teaching question followed by "Problem Identification", where the students determine this leading teaching question. Further hypotheses ("Hypothesizing") are gathered, and a "Processing Sequence" is discussed subsequently, which involves the processing of the question using materials such as maps, texts, illustrations, and diagrams. Finally, the hypotheses initially collected are verified or falsified ("Hypothesis Testing") based on the acquired information, and the resulting solutions are reflected upon ("Reflection of the Solution") by reflecting on the strategies used to reach the solutions or the transferability to the own environment, for example.

Topicality has high relevance in geography lessons meaning the following items were included in the Documentation: "Topicality", "Recognition through the students", and "Importance for students". In this way, the teachers had to document the topic's topicality and relevance in terms of content and record their perceptions towards the students they taught (Haversath, 2013). Multiperspectivity also included "Different Stakeholders", which is the common way of using multiperspectivity in geography lessons. The approach to a topic in consideration of spatial and temporal aspects (i.e., "Scale of space" and "Scale of time") has been widely discussed in current geographic educational research, as is the consideration of different "Spatial concepts". Finally, the "Student opinion" and its justification ("Student justify opinion") was documented as a form of changing perspectives (Rhode-Jüchtern, 2013). The category "Evaluation of the deep structure" was based on Kramis's (1990) work using questionnaires of self-reflection of teaching.

Consequently, the instruction quality, student- and competence-orientation, and the teacher-student relationship were documented, where teachers were able to grade themselves within individual sub-categories. The quantitative data collected from the Documentation were analyzed via SPSS and Excel, which focused on frequency distribution to visualize the teachers' action patterns and their change over time. Simultaneously, this method benefited from the individual generation of data and an intensive examination of personal actions.

\subsubsection{Weekly Review}

The Weekly Reviews aimed to confront teachers with their own recorded data to support them in identifying patterns in their teaching, be it patterns in the form of a chronological structure, a lack of a specific method, or a deficit in using geography education principles. With this method, we aimed to initiate a reflection on routines (cf. 2.3.2). It was also interesting to understand the extent to which teachers accept and evaluate this form of feedback. Weekly, every teacher who documented his or her lessons received a summary of their data by e-mail. The teachers received at least two data sets, one data set per Documentation of a single class, and one data set containing all data of the Documentation. We graphically prepared the data sets (bar charts and pie charts) and designed them to be as reader-friendly as possible to allow easy access. The data sets did not contain any interpretation. The method was based on the theories on e-portfolios (Keller, 2014) and the advantages of learning diaries as an instrument of teacher training (Landesprogramm Bildung und Gesundheit NRW).

\subsubsection{Team Discussion}

With the Team Discussion, we aimed for the advantages of communicating routines with colleagues (cf. 2.3.3) and getting additional qualitative data and information on assessing the Documentation and Weekly Reviews. Participants were divided into teams of two to three to have Team Discussions during the intervention. These discussions were scheduled to occur every 3 to 4 weeks, with the scheduling left to the participants themselves. Skype was used to support face-to-face exchange and was digitally recorded as the participating teachers came from different schools. The Team Discussions were planned to support teachers in exchanging the intervention experiences and talk about and reflect on the effects on their teaching and develop solutions for occurring difficulties. We expected to conclude the discussions about the extent to which the intervention's previous steps supported teachers in reflecting on their lessons and the changes they may have initiated in lesson planning or implementation. The Team Discussion recordings were transcribed and analyzed using interaction analysis (Krummheuer \& Naujok, 1999). It was essential to clarify patterns of interaction and communication between teachers, develop corresponding "meaning negotiations", and reconstruct these negotiation processes to identify strategies dealing with awareness, reflection, and communication of routines (Blumer, 1969; Krummheuer \& Fetzer, 2005, 16ff). 


\subsubsection{Final Interview}

The final interviews with the participants served as a conclusive evaluation of the study, including the targeted synthesis of previous findings of the Documentation, the Weekly Reviews, and the Team Discussions. A semi-standardized interview guide was developed (following Witzel, 1985) for this purpose, which included questions about the perception and evaluation of the intervention and questions about the aspects of reflection that were most supportive for the teachers and those that could be further improved. Through this specific approach, the teachers' subjective evaluation and perception patterns could be reconstructed with REROGLIT, views, and experiences with the reflection causes could be recorded, and techniques and routines that the teachers assign to their specific teaching experience could be analyzed and compared. In addition to the general questions on the opportunities and risks and the conditions for the success of REROGLIT, the questionnaire was partly extended by individualized questions in cases the data revealed incredibly exciting findings, as a significant change in the use of a particular method. The interviews were evaluated using a qualitative content analysis outlined by Mayring (2015). The aim was to categorize the corresponding evaluation patterns of geography teachers concerning the reasons for reflection.

\section{Results}

The results of our study are presented in this section. The study's components, Documentation, Weekly Reviews, and Team Discussions are presented individually. The research questions are consequently arranged as subheadings in each section to provide a better narrative.

\subsection{Results of the Documentation: Which Part of REROGLIT Contributes to Reflection and a Subsequent Change of Routines?}

Recordings of lessons that lasted 45 minutes were used for the analysis of the Documentation. To make possible changes in the lessons discernable, the Documentations of all teachers were bundled and then divided into two parts. The most appropriate time to divide the documentations into two parts was after the Team Discussions. Thus, the results presented refer to 25 lessons recorded before the Team Discussions (pre) and 20 lessons recorded after the Team Discussions (post), which will be compared to identify changes.

\subsubsection{Lesson Organization and Assessment of the Visual Structure of the Lesson}

Within the recordings on the lessons' visual structure, there were a large number of results, not all of which can be presented here due to limited space. Therefore, only the essential changes and results are presented, which will be referred to subsequently.

A constant three-phased structure of lessons (introduction phase, development phase, saving phase) was identified in the Documentation, as taught in German universities. However, the three-phased structure of the lessons was predetermined by the documentation sheet, the time allocated to each phase corresponded to that they were taught in academic education. Consequently, the introduction phase was relatively short (average time pre: $10 \mathrm{~min}$; average time post: $10 \mathrm{~min}$ ). The teachers allocated the largest part of the lesson to the development phase (average time pre: $22 \mathrm{~min}$; average time post: $19 \mathrm{~min}$ ), followed by the saving phase (average time pre: $13 \mathrm{~min}$; average time post: 16 min). Note that the time required for the development phase was reduced after the Team Discussion in favor of the saving phase. From this, we interpret a possible increase in awareness and willingness to change the lesson's time management aspect by the participating teachers through the course of the intervention. The multiple repetition and reflection on the saving phase with the help of the Documentation may have led to higher prioritization of the knowledge saving processes by teachers, and consequently to a change in the schedule of lessons. A more extended saving phase is crucial because it gives room for a more in-depth examination of the covered topic, more reflection and discussion time with the students to enable them to evaluate the leading lesson question and to form their own opinions, and thus a reliable "saving" of the results of the lesson.

Another result is assessing the lesson phases by the teachers, which is presented in Table 1.

Table 1. Grading of the Lesson Phases by the Teachers

\begin{tabular}{llll}
\hline & Introduction phase & Development phase & Saving phase \\
\hline Average $_{\text { grade }}$ pre & 2,0 & 3,1 & 2,5 \\
Average grade $_{\text {post }}$ & 1,7 & 1,7 & 2,2 \\
\hline
\end{tabular}


Generally speaking, it can be stated that in the course of the Documentation, the teachers became more satisfied with their teaching phases. The results show that the perception (assessment) of all teaching phases has improved during the Documentation. From this perspective, it could be interpreted that the temporal adjustment of the teaching phases shown above, i.e., the shortening of the development phase and the extension of the saving phase, is perceived positively by the teachers.

\subsubsection{Principles of Geography Education}

Figure 3 shows the results of the realization of the problematization principle in the documented lessons. Numerous changes were observed during the Documentation. To begin with, the general relevance of problem orientation in the documented lessons increased. This is shown by "Irrelevant in this lesson", appearing less often or not in the later documented lessons in all examples. Besides, an increase in the documented execution of almost all items can be seen. This includes "Problematization", "Hypothesizing", "Processing Sequence", "Hypothesis Testing", and "Reflection of the Solution" (see 4.1.1). This further supports the statement that there was a general increase in the relevance of more problematization in lessons throughout the Documentation.

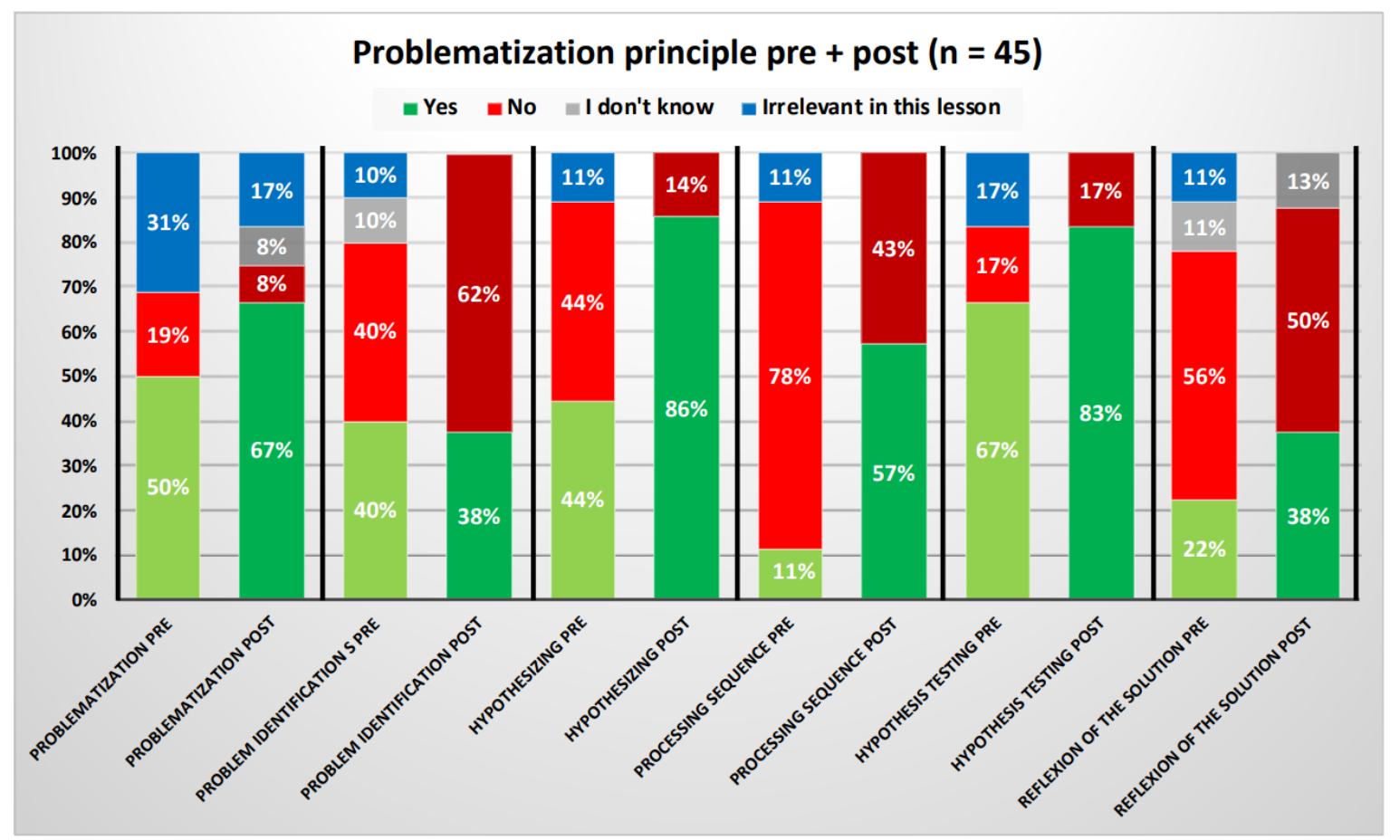

Figure 3. Changes within the Problematization of the Lessons (Own Illustration)

An interesting observation is that there was no documented increase in the "Problem Identification" i.e., the identification of the lesson problem by the students. This could be because the teachers continued to address the leading problem of the lesson themselves, or they were not sure whether the students understood the question. Reasons for this could be the teachers tried to keep control on the effective maintenance of the lesson phases, i.e., the extension of the saving phase or they lacked the methodological skills to implement "Problem Identification". In contrast, "Hypothesizing", "Procession Sequence", and "Hypothesis Testing" showed significant increases. In addition, an increase in the "Reflection of the Solution", i.e. metacognitive phases in class, was documented by the teachers, which could be due to the fact that the increase in the problematization of the lesson increased the need for critical reflection on the topic or because self-reflection within the framework of the Documentation may have led to increased sensitivity towards reflection phases in class.

In summary, it was possible to identify changes in the documented problematization of the lesson throughout the Documentation, particularly in the hypothesis formation, discussion of the processing sequence, hypothesis checking and reflection of the solution. This leads to the assumption that raising awareness and possibly a reflection on deficits within the problematization of the lesson may increase awareness of personal routines and thus may support the 
implementation of this principle.

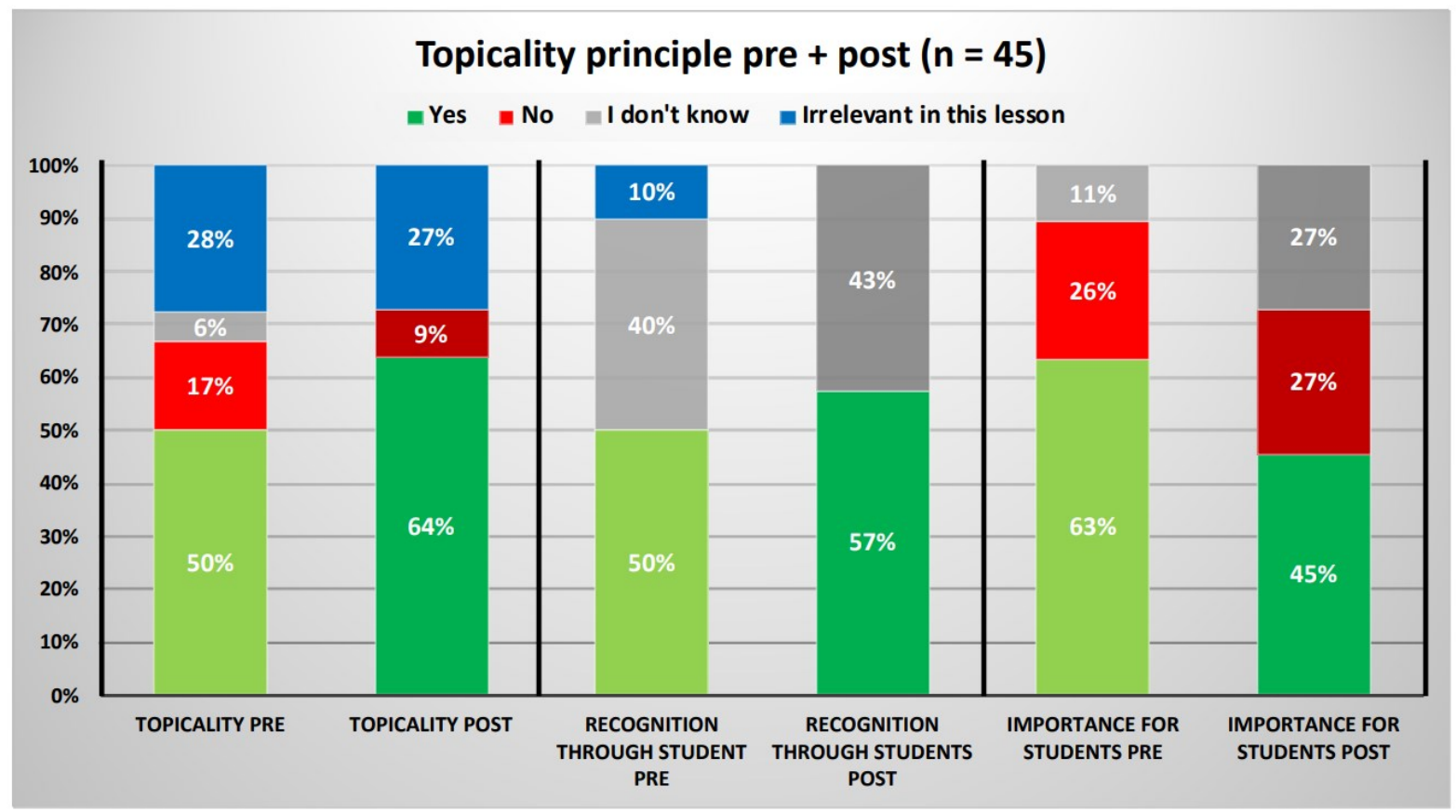

Figure 4. Changes within the Topicality of the Lesson (Own Illustration)

The topicality principle results show that the documented topicality of the lesson topics ("Topicality") increased during the Documentation. However, although teachers increased the importance of topicality during the intervention ("Topicality pre": 50\% compared to "Topicality post": $64 \%$ ), and teachers perceived that students also recognized this topicality ("Recognition through the students": $+7 \%$ ), the interest and importance for students of the perception of the teachers ("Importance for students") fell (-17\%). This may be since the selection of topics was not planned with the students' needs in mind. In addition to the documented increase in topicality overall, the results show that there was also an increase in uncertainty ("I don't know") among the teachers when it came to documenting the extent to which the topicality was significant for the students' learning environment ("Importance for students pre": $11 \%$ to "Importance for students post": 27\%). The same applies to the perception of the teachers with regards to students recognizing the topicality of the lesson topic ("Recognition through Students pre": $40 \%$ to "Recognition through Students post": $43 \%$ ). This uncertainty may be explained by the fact that the awareness of the principle and its importance for geography lessons led to reflection on their deficits with this principle, which triggered uncertainty. Overall, the lesson's topicality seems to be an essential concern for the teachers due to the results, especially in conjunction with students' uncertainty. This finding was not only clear here but also in the results shown in Section 5.1.3.

The multiperspectivity principle results showed a generally low relevance of perceived multiperspectivity in the documented lessons throughout the whole Documentation. For example, the use of different stakeholders ("Diff. Stakeholders pre/post"), the most common implementation of multiperspectivity in geography education, was not relevant in $29 \%$ and $45 \%$ of the documented lessons, respectively. Furthermore, the actual use of different stakeholders decreased during the intervention by $17 \%$. If aspects of multiperspectivity were documented and possibly implemented in the class, they were more likely to be in conjunction with spatial and time scales ("Scales of Space" and "Scales of Time", cf. chapter 4.1.1), and an increase was documented in both items $(+35 \%$ in Scales of Space and $+4 \%$ in Scales of Time). It was also noticeable that at the start of the Documentation students' opinion ("Student Opinion pre") were asked for by the teachers in $71 \%$ of the documented lessons and subsequently justified in most cases ("Students justify opinion pre": 83\%), but this changed throughout the intervention with fewer student opinions asked for by the end ("Students Opinion post": 40\%). It is interesting to note that, despite the low level of requests for students' opinions, these opinions' justification remained high. This might be to do with the already described trend of teachers tending to focus more on their planned lesson structure and the lesson's conclusion, particularly (see chapter 4.1.1). 


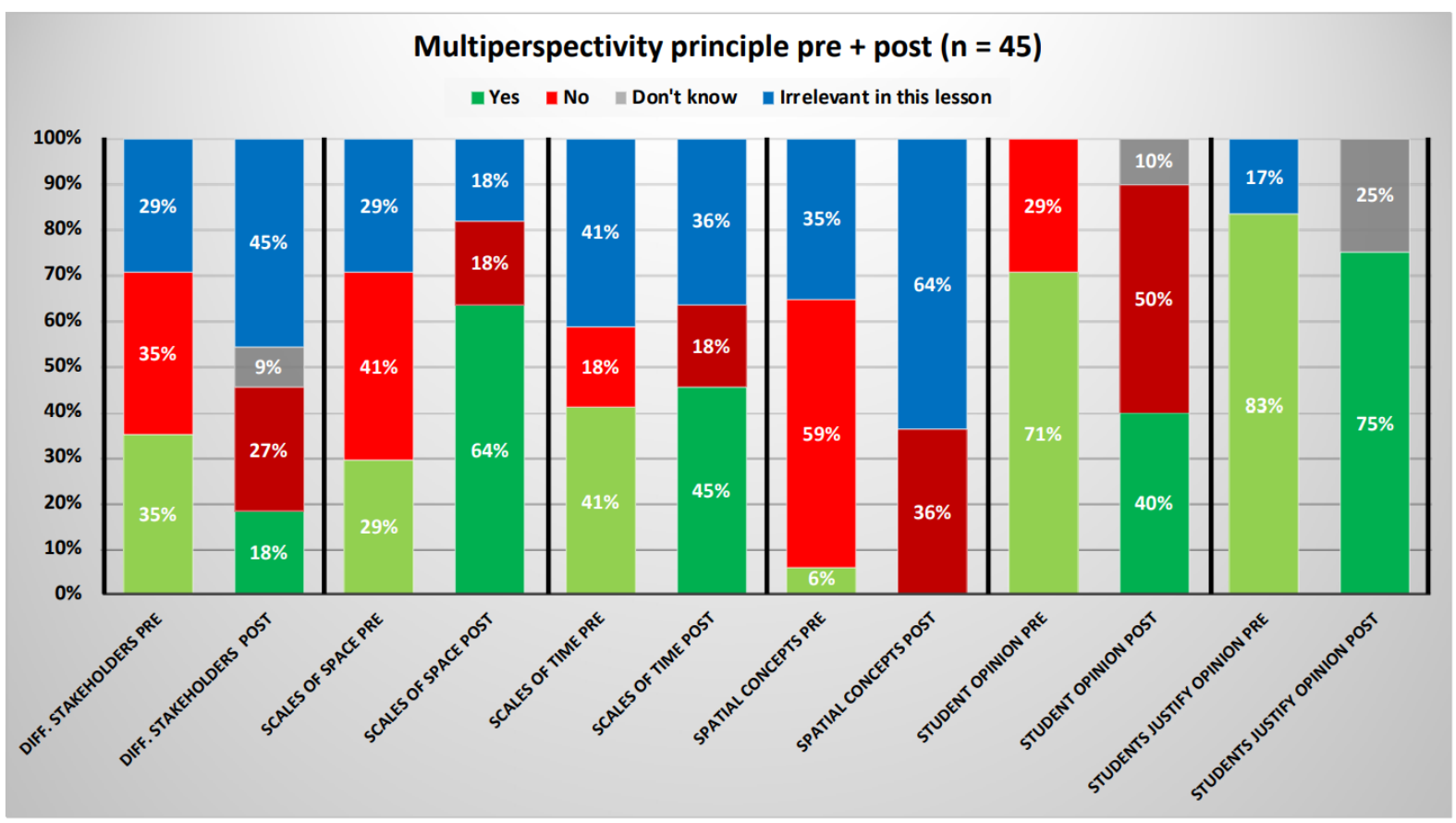

Figure 5. Changes within the Multiperspectivity of the Lesson (Own Illustration)

\subsubsection{Classroom Management and Evaluation of Personal Teaching Practice}

Table 2 summarizes the average grades given by teachers to themselves using the given criteria. The categories include several items that are not shown here due to lack of space. When comparing the grades documented for the intervention, it is noticeable that in almost all categories, the teachers' self-grading improved over time. This could be explained by knowledge of, and reflection on, the individual criteria meant that the teachers' actions over time became more conscious with regards to the planning and articulation processes. Furthermore, through continuous documentation, this raising of awareness may have caused a renewal and refreshment of skills and knowledge so that existing academic knowledge and teaching skills can be used again. Conversely, it is possible that teachers see hardly any deficits in themselves and therefore, no reason for change. Another explanation could be to do with the social desirability upon which the teachers graded themselves so favorably. They may have been worried about meeting either the researcher's expectations or expectations and wanted to portray a positive self-image (about social rejection). Exceptions to the good grades are the student orientation and the competence orientation (see Table 2), where grades are worse relative to those of the other categories. Reasons for the lower grades could be uncertainty and possibly a lack of understanding regarding the item in question. It seems that if teachers consider themselves to have a good relationship with their students, they also have good classroom management and good instructional skills, but are unsure if their students perceive this in the same way and whether they reach all pupils with their lessons.

Table 2. Comparison of Average Grades of the Evaluation of the Lessons by the Teachers according to Predefined Criteria (lesson)

\begin{tabular}{lccccc}
\hline & $\begin{array}{c}\text { Teacher-student } \\
\text { relationship }\end{array}$ & $\begin{array}{c}\text { Classroom } \\
\text { management }\end{array}$ & Instruction quality & Student orientation & $\begin{array}{c}\text { Competence } \\
\text { orientation }\end{array}$ \\
\hline Average gradepre & 1,3 & 1,5 & 1,9 & 2,6 & 3,0 \\
Average grade $_{\text {post }}$ & 1,2 & 1,8 & 1,7 & 2,4 & 2,2 \\
\hline
\end{tabular}

4.1.4 How Does REROGLIT Contribute to a Reflection on Teaching and Changes in Geography Teachers' Teaching Routines? 
Table 3 shows that neither the Documentation nor the Weekly Reviews were well graded by the teachers. Teachers were able to mention various problems they had with the Documentation in the interviews.

Table 3. Assessment of the Documentation and the Weekly Review by the Teachers

\begin{tabular}{lcc}
\hline & Documentation $(\mathrm{n}=25)$ & Weekly Review $(\mathrm{n}=11)$ \\
\hline Average grade $_{\text {pre }}$ & 2,8 & 5,0 \\
Average grade $_{\text {post }}$ & 3,7 & 5,0 \\
\hline
\end{tabular}

One problem was, that some of them had the impression they could not record all relevant aspects of their lessons on the observation sheet:

"Yes, because I just had the feeling that my phasing was sometimes not clearly separable, it was challenging for me to indicate this phasing in the Documentation."

This shows that, from the teachers' point of view, no conclusions could be drawn from the Documentation concerning teacher personality. A further difficulty that the teachers noticed was the regularity and time requirement (by) of the Documentation:

"[...] I have no time, I have stress. I have a hundred other things to do, and I have often found it difficult to record this regularly, [...]."

If the Documentation was completed at a later date to the lesson, the results became less accurate as the memory of the lessons fades. Lastly, some teachers found it challenging to grade themselves based on standardized grades:

"Yes, it was sometimes a bit difficult to find one's way on that scale of one to six."

Nevertheless, the Documentation was positively received in many ways. For some teachers, the Documentation helped them to reflect on their own lessons:

"So this documentation of the lessons was definitely helpful. Precisely because you start to think about your lessons, which you might not otherwise do or would not do in such detail."

"For my own reflection, I found it quite good that one divided into the different phases of the lessons and the methods one used because, in the end, one could see: Oh, I use that one method a lot, and maybe I could do something different. I really liked that."

Furthermore, the Documentation revealed deficits and unconscious routines:

"And as I said, it struck me that if you've been negative about one thing all the time, you've noticed that through this documentation. It makes a lot of sense because otherwise you would never think about certain things. And that just triggers something. I mean, what you make of it is another question. I haven't started consciously yet; I have to do this and that and that. But at least I know now that it is one of those things that I could and should tackle."

Moreover, from this comment, there is another effect that the Documentation has triggered, which is insecurity caused by pointing out some teachers' shortcomings. In the commentary above, it is evident that the teacher became aware of their deficits, but corresponding actions were not considered. This insecurity was equally apparent in other passages:

"Well, I found it a bit depressing at times that you just sat there and said, yes, I know that this is possible and should be possible.[...] At times I thought, yeah great, I wanted to do that and now the first two weeks were spent in the internship [by the students] and then came holidays."

"I completed this questionnaire [the Documentation], and at some point, I got desperate, [...]. Then sometimes you feel a bit: Okay! I'm a bad teacher."

An exciting aspect of these comments is that there is not only a cognitive awareness about teaching deficits but also a doubt of the personal competencies as a teacher in general. We had not planned for this result, and we do not see this as a success of the method, but rather as a danger because teachers could become frustrated, which would inhibit the process of further reflection. Ultimately, the discussion and reflection of the deficits that have become apparent should occur in the Team Discussions and could dissolve the possible frustration.

Consequently, our objective for the Documentation was successful in initiating awareness of deficits and harmful, 
unwanted routines. Despite the lousy grading, the teachers saw the Documentation's strength in highlighting aspects of lesson organization, such as the phasing of lessons, which had not been clear before, and thus uncovered unknown routines and tackled them accordingly. It may be that a slight trend that the teachers focus on the visual structure of the lessons with the organization and articulation of the lessons. The teachers are aware of the subject-related level and the depth structure level but do not focus on it in their daily work. This mainly concerns the "depth structure of teaching" the grades in Table 2 show that the teachers see themselves very positively and do not seem to have any deficits.

4.2 Results of the Team Discussion: Which Part of REROGLIT Contributes to Reflection and a Subsequent Change of Routines?

The Team Discussion aimed to support teachers reflecting with each other and find solutions for deficits documented through the documentation process and benefit from the practical expertise of the other team member.

An exchange of experiences should occur in which the teachers discuss and reflect on the effects of the intervention on their lessons and, if necessary, identify problems and formulate appropriate solutions. The results already presented regarding the teachers' uncertainty in the recognition and importance of topicality by the students (cf. 4.1.2) or in the lower grading of student and competence orientation (cf. 4.1.3) caused by the Documentation were further confirmed within the Team Discussion. In the following sections, the results of the interaction analysis are presented, and it is shown the extent to which the perceived deficits have been dealt with collectively and how solution strategies have been developed together. Four different strategies could be observed during the discussions:

\subsubsection{Teachers' Strategies for Dealing with the Uncertainty Caused by Documentation}

\section{a) Criticism of the Method}

During the Team Discussions, difficulties with the Documentation were discussed. This led to discussion of the perceived deficits as being considered relative and considered meaningless. The following text passage shows how the two interacting teachers strengthened each other in this interpretation approach:

A: "Now I don't even know when to mark it [Documentation of methods]. If I have used it or if the students have used it or so. Well, that's definitely..., somehow it has led to confusion for me."

B: "So I notice that already. Yes, but I don't quite know what this tool means for you in the end. If it should show you your own mistakes or if it should make me look stupid in the end, because that's what I found the hardest to do, that what is shown here in this self-evaluation."

Here, the Documentation goal where deficits should be identified and then worked on individually and as a team through discussion with another teacher is not recognized. This shows that teachers do not see the Documentation as a supportive tool, but rather as an additional compulsory task that is a burden, and do not see any additional gain for themselves by filling it out. Professional handling of the deficits or proposed solutions did not take place in this way. The perceived deficits were not attributed to themselves, but the survey instrument and no solutions were discussed or developed.

\section{b) Making the school environment responsible for deficits:}

Another strategy to deal with the uncertainty regarding the teachers' own performance was to look for and justify possible individual deficits in the school facilities:

A: "I have often thought, [...], I would like to try all these things, but [...] also the equipment of our school and if I had the time to think of something new, then perhaps I would also lack the ideas of what or then it would take too long."

B: Well, you can do other things...

This demonstrates that although the willingness to innovate is there, it is not feasible due to school equipment and lack of time, or the will to change one's own actions is simply not there, and that deficits in one's own teaching are then attributed to "overpowering" unsuitable conditions.

\section{c) Making the student performance responsible for deficits}

A similar strategy that was observed from the Team Discussion was that the teachers, when considering their personal deficits, saw the students' performance as the reason for them:

A: The students have been too slow in this development phase and we have to make sure that they are correct. Then it was difficult to document, the development phase, the saving phase, because you thought it 
was okay, so I started the saving phase in the last lesson.

B: Yeah, like that. That's just...

A: Then it will stop, then it will fit, then it will not be so easy to fill in the questionnaire.

This shows that there were problems with the Documentation due to the pupils' performance in teacher's perspective. This is interesting in so far as the teachers did not see a problem in their personal time management but considered the "too slow students" as a problem for their time management and thus the problem with documenting their lesson.

Instead of developing constructive solutions for their deficits, some teachers blocked with ironic comments on student characteristics:

B: "Well, we're supposed to find out our habits and then break them up a little bit when it makes sense to break them up. Yes, well, if we now always state at the end, yes, we are thinking in terms of the world we live in, but the students don't check it, then I have to try to get them to check it."

I: "So now we could say that we have to try to make it more transparent to what extent this is related to the live environment of the students."

B: "Yes. At best by the fact that the students themselves recognize, by their high intrinsic motivation [...]."

I: "Yes, the high intrinsic motivation, I would also like to address that at this point."

B: "Yes, I would like to buy it somewhere."

I: "Can you get them on Amazon?"

It is again about the fact that from the teacher's perspective it is impossible to teach better lessons with students who lack motivation. In this context, the use and improvement of the topicality principle was discussed and even a temporary solution was suggested ("[...] that we have to try to make it more transparent to what extent this is related to the live environment of the students"). But this was ridiculed by referring to the "high intrinsic motivation" with an ironic intonation and the further reference to it, joking that it is only available for purchase. Thus a final solution was not reached or discussed further, and it is questionable as to whether substantial changes in action are realized in class.

d) Encourage-comfort-seek confirmation and satisfaction with their own teaching

Some teachers encouraged themselves with similar experiences that they had in the course of the intervention in order to avoid the solution of possible deficits. The aim of the teachers was to maintain a positive professional self-image and not to address individual aspects that could be explicitly improved.

A: "And it was somehow quite nice to sit there together, thinking that we were both teachers for a while.

We certainly don't do the worst teaching and we feel the same that we are in a situation where you think, yes, if someone were to look now, it wouldn't be so great. But you know, okay, we're trying to improve that."

The passage shows that the teachers use the situation to strengthen their group identity and a "sense of we" (e.g. "We certainly don't do the worst teaching" or "we feel the same". They support their professional self-image and indirectly address the deficits that have emerged from the Documentation ("if someone were to look now, it wouldn't be so great"), but there is no discussion about a possible solution for these deficits. There were no arguments or conflicts in any of the team sessions. The participating teachers were very sympathetic and cooperative with each other. If, for example, something didn't work, this was approached sensitively, and consolation was given accordingly:

C: "And what you mention right now, the problematization. I also have a lesson in which that was completely irrelevant. So as you do. And then I somehow didn't understand why I had to push it through once, when the lesson before, for example, counts as an absolute practice lesson."

D: "Right. And you don't make hypothesizing every lesson. So it's just not relevant and I think that if I now look at my problematization here, I get a very bad conscience about how my week of lessons was."

C: "Was all right."

The teachers seek agreement, harmony and confirmation from one another ("So as you do" or "Right. And you don't make hypothesizing every lesson"). This example shows that although a deficit in the problematization of the lesson was registered, it is put into perspective by a comforting "was all right" and the actual problem is not further investigated. The perceived problems and associated bad consciences are suppressed intentionally. 


\subsubsection{In What Way do Teachers Perceive and Evaluate Individual Opportunities for Reflection Using REROGLIT?}

Overall, it can be stated that the Team Discussion did not give the expected result. The collaborative reflection and formulation of possible solutions only worked for a small number of deficits that have become apparent to the teachers through the Documentation. One of the main issues addressed was that the discussions were too superficial and not goal-oriented. While lessons were being discussed and reflected upon, there was no professional discussion about deficits and their solution. Specifically, the teachers were aware that the instructional articulation was not clear enough, that the saving phase was too short, that difficulties and uncertainties with pupil orientation exist, and that the topicality principle is sometimes challenging to implement (see 4.1.4). All of these deficits and more were named and addressed, but a professional elaboration of a solution was avoided with at least one of the strategies described above. The teachers in the Team Discussions likely regarded them as a kind of "compulsory exercise" in the intervention course so that social desirability and the associated effect of social rejection repeatedly had a strong influence here. Another reason could be that the teachers are not used to conducting professional educational discussions. Furthermore, it could be that teachers in general, due to the time-intensive school routine, do not seek professional support and, therefore, do not know how to deal with criticism in a professional way.

\section{Discussion \& Conclusion}

In conclusion, we can answer the question to what extent REROGLIT has contributed to the reflection of personal teaching and changes in individual routines in lessons as follows: Overall, the intervention was successful in fulfilling the basic idea of the approach, i.e., the confrontation with personal routines, the awareness of deficits, the initiation of reflection processes, and the recognition of the need for change. It was shown that the teachers involved were insecure about their knowledge and awareness of deficits. We did not expect these kinds of effects on the professional insecurity of their role as a teacher and questioning their competence as a teacher that the Documentation had on the teachers to this extent.

In contrast, real changes in lessons only partially succeeded. Within the presented results, this could be shown in some aspects, such as the extension of the saving phase and geographic education principles. Hence, it can be stated that the Documentation led to reflection and in parts also to changes in the lessons. However, it also became apparent that although there was an awareness of deficits, new actions were only partially carried out. This can be explained by a lack of metacognitive experience, as described in Chapter 3.2, as the results show that teachers have only a limited awareness of the quality of their lessons on an objective, scientific basis, and consequently, a possible denial of reflectivity. Moreover, it could be a lack of incentives, lack of know-how, or merely appreciative feedback. Either way, this result shows that it is not enough to point out deficits - there was a willingness to change in some teachers, but too many obstacles, like time pressure or standardized grading, are perceived by the teachers to prevent change. For future studies, the following changes in the Documentation are suggested: The Documentation should be made shorter by a less extensive query of categories, but with more differentiation between categories to identify particular routines and thus lead to more apparent changes if necessary.

Furthermore, the Weekly Reviews and the Team Discussions did not achieve the intended effect. Team Discussions were the foremost opportunity for teachers to trigger change processes by benefiting from each other's expertise. Unfortunately, they were not perceived as such because the communication about the lessons was only reflected in limited parts, and possible solutions for modifying deficits were only suggested occasionally.

In this context, teachers' strategy to assign errors and problems in the execution of lessons to external circumstances and the emotion of insecurity in their behavior and actions can be explained with the help of attribution theory (Heider, 1958). The results presented are an uncontrollable, external, stable, and global case (Weiner 1986): they are perceived as controllable as the errors and the associated uncertainty cannot be influenced from the teachers' point of view. They are perceived to be external as the causes of error are sought in the environment, and they are perceived to be stable as the cause is considered unchangeable and finally global because the strategy is found in several situations and does not occur only once.

The shortcomings of the Team Discussion can also be found, for example, in reflecting teams (cf. Reich, 2003), which is a similar approach to evaluating lessons in groups. Likewise, in teacher discussions on mutual class observation, only very cautious feedback was given, and only positive things were highlighted so that the teachers showed an uncritical attitude and perceived such reflections as a farce. The danger Reich (2003) identified consisted of unclear observation orders, the unclear value of the observations (recognition), and no agreed consequences. These findings could also be transferred to our Team Discussion. Although clear documentation orders were given, no specific 
consequences were agreed upon but were instead expected by the teachers. It would probably have required professional moderation by the researcher to make the Team Discussion a success through better structuring. Teachers have minimal experience supporting each other professionally, as this is not practiced in their academic and practical education. For example, prospective teachers from their legal traineeship receive professional support from their supervisor but are bound to him or her by a hierarchical assessment. In addition to the deficits, the strengths and the personal goals of each teacher could have been addressed in a more targeted manner so that the strategies for dealing with the perceived uncertainty shown in the results would not have been a central part of the discussions so that the discussion would have been more solution-oriented. The willingness for critical reflection was stated in parts but without specific proposals for change.

At this point, reference can be made to Tiefel (2004), Weyland (2010), and Müller (2010), who promote a balanced reflection in which several different levels (cf. Weyland, 2010) are taken into account. Moore (2007) demands, similarly to Weyland (2010), that teachers should reflect on their behavior and the relationship to others, on experiences and their conditions of origin and contextualization, to understand what influences their actions. Thus, reflection does not consist of constant self-criticism, but rather in a social contextualization of personal actions. However, our results showed that even if different reflection possibilities are given, such as in social interaction with like-minded people to critically and reflexively deal with their actions, no change occurs. At this point, it becomes clear that teachers need to show a willingness for self-reflection because the teacher themselves can also initiate the cycles of reflection. Therefore, teachers are expected to have a confident attitude towards their profession and be motivated to develop it further (Copeland et al., 1993). For example, Dewey (1933) pointed out that individual attitudes, in particular, and not only knowledge, contribute to reflective thinking. As attitudes are fundamental for this, Dewey identified three essential and critical aspects of attitude:

1. Open-mindedness, understood as openness to new ideas and explanatory approaches.

2. Whole-heartedness, understood as enthusiasm that leads to an intensive examination and further exploration of a matter.

3. Responsibility, which means taking responsibility for processes from the beginning to their consequences.

Hence, certain beliefs related to an individual's ability to generate knowledge and actions play an essential role in reflection, which points to the importance of epistemological beliefs. These also relate to the generation and validity of knowledge. Similarly, Bromme and Haag (2004) demand a teacher who is characterized by the ability to engage in informed dialogue, meaning the ability to search for and receive information in a targeted manner for problem-solving throughout one's professional life, which should also be taught at university and during teachers' traineeships. As shown above, scientific theories cannot just be implemented. The teacher must be able and motivated and engage in a professional and critical exchange with themselves and others about their actions. As a result, the confrontation with deficits hardly changed even subjective theories and individual convictions. It was only in a retrospective view (cf. Final Interviews) that individual teachers received a positive evaluation of some individual possibilities for reflection.

The presented study and the developed reflection tool are still at the very beginning of their use in everyday lessons. Nevertheless, some findings can be transferred to current teaching development. For example, the Team Discussions' main finding is that teachers are not trained well enough for professional feedback, which could be included more in university, the legal traineeship, and later teacher training courses. The shown results can be compared with already empirical results from teacher training research in geography education (Fögele \& Mehren, 2015b). In this context, teacher training's low effectiveness and a gap between teaching practice and available theoretical concepts have already been highlighted. Furthermore, the Documentation could be modified without great effort for further research purposes to look at teachers' professional competence development to document specific aspects, such as the student-teacher relationship, to state (unwanted) routines in this area. From a research perspective, the attempt to build a bridge between knowledge in the form of an awareness of deficits and action was only partially successful. Routines were occasionally broken and inert knowledge activated, but minimal new action took place. Teachers' professional competence development mustn't be regarded as completed after the academic education and the legal-traineeship. Teachers need to be supported in observing, reflecting, and developing improvements in their teaching. This is where our results show a possible approach that could be further developed based on the critical discussion presented here. This result can be linked to the perspectives of geographic education research (Hemmer, Bagoly-Simó \& Hemmer, 2018). A meta-analysis found out that future research subjects of geographic education research will be teachers and that the optimization of teacher training will be in focus. Therefore, a targeted awareness of deficits is essential. Otherwise, there is no reason for a change. In this context, there must be a possibility of a sustainable training of reflective skills in universities, teacher training, and schools, which should be accompanied by research. 


\section{References}

Altrichter, H., \& Posch, P. (2007). Lehrerinnen und Lehrer erforschen ihren Unterricht. Bad Heilbrunn: Klinkhardt.

Baumert J., Kunter, M., Blum, W., Brunner, M., Voss, T., Jordan, A., Klusmann, U., Krauss, S., Neubrand, M., \& Tsai, Y.-M. (2010). Teachers' mathematical knowledge, cognitive activation in the classroom, and student progress. American Educational Research Journal, 47(1), 133-180. https://doi.org/10.3102/0002831209345157

Bromme, R., \& Haag, L. (2004). Forschung zur Lehrerpersönlichkeit. In Helsper, W. \& Böhme, J. (Eds.), Handbuch der Schulforschung (pp. 777-793). Wiesbaden: VS Verlag für Sozialwissenschaften.

Budke, A. (2012). Argumentieren im Geographieunterricht. Geographie und ihre Didaktik, 40(1), 23-34.

Blumer, H. (1969). Symbolic interactionism. Prentice-Hall, NJ, Englewood Cliffs.

Constable, J. F., \& Russel, D. W. (1986). The Effect of Social Support and the Work Environment upon Burnout among Nurses. Journal of Human Stress, 12, 20-26. https://doi.org/10.1080/0097840X.1986.9936762

Copeland, W. D., Birmingham, C., de la Cruz, E., \& Lewin, B. (1993). The reflective practitioner in teaching: Toward a research agenda. Teaching and Teacher Education, 9(4), 347-359. https://doi.org/10.1016/0742-051X(93)90002-X

Dewey, J. (1933). How We Think. A Restatement of the Relation of Reflective Thinking to the Educative Process. Lexington: D. C. Heath and Company.

Efklides, A. (2009). The role of metacognitive experiences in the learning process. Psicothema, 21(1), 76-82.

Felzmann, D. (2013). Problemorientierter/-lösender Unterricht. In D. Böhn \& G. Obermeier (Eds.), Wörterbuch der Geographiedidaktik. Braunschweig, Deutschland: Bildungshaus Schulbuchverlage.

Flavell, J. H. (1979). Metacognition and cognitive monitoring. A new area of cognitive-development inquiry. American Psychologist, 34(10), 906-911. https://doi.org/10.1037/0003-066X.34.10.906

Flavell, J. H., \& Wellman, H. M. (1977). Metamemory. In R. V. Kail, Jr. \& J. W. Hagen (Eds.), Perspectives on the development of memory and cognition (pp. 3-33). Hillsdale, NJ: Erlbaum.

Fögele, J., \& Mehren, R. (2015a). Merkmale wirksamer Lehrerfortbildungen - Empirische Evidenzen aus der Bildungs-/Unterrichtsforschung und daraus resultierende Empfehlungen für die Geographiedidaktik. Zeitschrift für Geographiedidaktik | Journal of Geography Education, 2(15), 81-106.

Fögele, J., \& Mehren, R. (2015b). Empirische Evidenzen der Lehrerfortbildungsforschung und daraus resultierende Empfehlungen für die Geographiedidaktik. Zeitschrift für Geographiedidaktik | Journal of Geography Education, 2(15), 1-25.

Fögele J., Mehren, R., \& Rempfler, A. (2020). Wissen vernetzen - Concept Maps im Geographieunterricht. Praxis Geographie, 4, 10-14.

Franz, H. J. (1986). Bewältigung gesundheitsgefährdender Belastungen durch soziale Unterstützung in kleinen Netzen. Konstanz: Hartung-Gorre.

Gage, N. L., \& Berliner, D. C. (1996). Pädagogische Psychologie (5th ed.). Weinheim: Beltz.

Haas, A. (1993). Lehrern bei der Unterrichtsplanung zugeschaut. Oder: Didaktik zwischen Theorie and Alltag. Pädagogik, 45(10), 46-48.

Haas, A. (1998). Unterrichtsplanung im Alltag. Eine empirische Untersuchung zum Planungshandeln von Hauptschul-, Realschul- und Gymnasiallehrern. Regensburg: Roderer Verlag.

Haas, A. (2005). Unterrichtsplanung im Alltag von Lehrerinnen und Lehrern. In A. A. Huber (Ed.), Vom Wissen zum Handeln. Ansätze zur Überwindung der Theorie-Praxis-Kluft in Schule und Erwachsenenbildung (pp. 5-20). Tübingen: Verlag Ingeborg Huber.

Haversath, J. B. (2013). Aktualitätsprinzip. In D. Böhn \& G. Obermeier (Eds.), Wörterbuch der Geographiedidaktik. Braunschweig. Deutschland: Bildungshaus Schulbuchverlage.

Haubrich, H., \& Brucker, A. (2006). Geographie unterrichten lernen. Die neue Didaktik der Geographie konkret. München.

Häcker, T., \& Rihm, T. (2005). Professionelles Lehrer(innen)handeln - Plädoyer für eine situationsbezogene Wende. In G.-B. von Carlsburg \& I. Musteikiene (Eds.), Bildungsreform als Lebensreform (pp. 359-380). Frankfurt a. M.: 
Peter Lang.

Heider, F. (1958). The Psychology of Interpersonal Relations. Kansas, USA: John Wiley \& Sons, Inc. https://doi.org/10.1037/10628-000

Helmke, A. (2012). Unterrichtsqualität und Lehrerprofessionalität. Diagnose, Evaluation und Verbesserung des Unterrichts. Seelze.

Hemmer, I., Bagoly-Simó, P., \& Hemmer, M. (2018). Perspektiven geographiedidaktischer Forschung. In G. Weißeno, R., Nickolaus, M., Oberle \& S. Seeber (Eds.), Gesellschaftswissenschaftliche Fachdidaktiken, Empirische Forschung in den gesellschaftswissenschaftlichen Fachdidaktiken (pp. 81-92). Wiesbaden: Springer Fachmedien. https://doi.org/10.1007/978-3-658-18892-4_5

Keller, S. D. (2014). E-Portfolios als Lern- und Prüfungsinstrumente in der Lehrerinnen- und Lehrerbildung. Beiträge zur Lehrerinnen- und Lehrerbildung, 32(1), 120-134.

Konrad, K. (2005). Vom Wissen zum Handeln - Kognitionspsychologische Betrachtungen. In A. A. Huber (Ed.), Vom Wissen zum Handeln. Ansätze zur Überwindung der Theorie-Praxis-Kluft in Schule und Erwachsenenbildung (pp. 39-58). Tübingen: Verlag Ingeborg Huber.

Koschmann, T., Kelson, A., Feltovich, P., \& Barrows, H. (1996). Computer-supported problem-based learning. In T. Koschmann (Ed.), Theory and Practice of an Emerging Paradigm (pp. 83-124). Mahwah, NJ: Erlbaum.

Köller, O. (2014). Classroom Management, konstruktive Unterstützung und kognitive Aktivierung: Kerndimensionen gelingenden Unterrichts. Lecture at the University of Oldenburg on 23.09.2014.

Kramis, J. (1990). Bedeutsamkeit, Effizienz, Lernklima. Grundlegende Gütekriterien für Unterricht und didaktische Prinzipien. Beiträge zur Lehrerinnen- und Lehrerbildung. 8(3), 279-296.

Krohmer, M., \& Budke, A. (2018). Understanding and Assessment of Innovation by Geography Teachers in North Rhine-Westphalia: A German Case Study. Review of International Geographical Education Online (RIGEO), 8(3), 415-439. https://doi.org/10.33403/rigeo.505228

Krohmer, M., \& Budke, A. (2019). Teaching Routines in German Geography Classroom: A Case Study in North Rhein-Westphalian Gymnasiums. In press.

Krummheuer, G., \& Naujok, N. (1999). Grundlagen und Beispiele Interpretativer Unterrichtsforschung. Opladen, Leske + Budrich. https://doi.org/10.1007/978-3-322-95191-5

Krummheuer, G., \& Fetzer, M. (2005). Der Alltag im Mathematikunterricht. Beobachten, Verstehen, Gestalten. München, Elsevier, Spektrum Akademischer Verlag.

Kuckartz, U. (2014). Mixed Methods. Methodologie, Forschungsdesigns und Analyseverfahren. Wiesbaden: Springer VS.

Kunter, M., \& Trautwein, U. (2013). Psychologie des Unterrichts. Paderborn.

KVFF $=$ Konferenz der Vorsitzenden Fachdidaktischer Fachgesellschaften. (1998). Fachdidaktik in Forschung und Lehre. Kiel.

LaRocco, J., \& Jones, A. P. (1978). Co-worker and Leader Support as Moderators of Stress-Strain Relationships in Work Situations. Journal of Applied Psychology, 62, 629-634. https://doi.org/10.1037/0021-9010.63.5.629

Linsner, M. (2012). Prototypische Routinen von Lehrkräften im Umgang mit Unterrichtseinstiegen, Experimenten und Schülervorstellungen im Biologieunterricht (Dissertation). Universität Duisburg-Essen, Essen.

Lude, A. (2001). Naturerfahrung und Naturschutzbewusstsein. Eine empirische Studie Forschungen zur Fachdidaktik (Band 2). Innsbruck: Studienverlag.

Mandl, H., Gruber, H., \& Renkl, A. (1993). Das träge Wissen. Psychologie heute, 20(9), 64-69.

Mayring, P. (2015). Qualitative Inhaltsanalyse. Grundlagen und Techniken. Beltz: Weinheim. https://doi.org/10.1007/978-3-531-18939-0_38

Meyer, H. (2014). Leitfaden zur Unterrichtsvorbereitung. Frankfurt/M: Cornelsen Scriptor.

Meyer, H., Feindt, A., \& Fichten, W. (2007). Was wissen wir über erfolgreiche Unterrichtsentwicklung? In Becker, G., Feindt, A., Meyer, H., Rothland, M., Stäudel, L., \& Terhart, E. (Eds.), Guter Unterricht. Maßstäbe \& Merkmale - Wege \& Werkzeuge (pp. 66-70). Seelze: Friedrich Verlag (XXV). 
Moore, A. (2007). Beyond reflection: contingency, idiosyncrasy and reflexivity in initial teacher education. In Hammersley, M. (Ed.), Educational Research and Evidence-Based Practice (pp. 121-138). London: Sage.

Müller, S. (2010). Reflex, Reflektion und Reflexion. Dimensionen von Reflexivität in der Lehramtsausbildung. In Liebsch, K. (Ed.), Reflexion und Intervention. Zur Theorie und Praxis Schulpraktischer Studien. (pp. 27-52). Baltmannsweiler: Schneider.

Reinders, H. (2005). Qualitative Interviews mit Jugendlichen führen. Ein Leitfaden. München: Oldenbourg.

Reinfried, S. (2007). Welche Unterrichtsstrategien verändern geographische Alltagsvorstellungen nachweislich? Eine empirische Studien zum Conceptual Change am Beispiel subjektiver Theorien über Grundwasser. Geographie und ihre Didaktik, 35(1), 20-40.

Rempfler, A. (Ed.) (2018). Wirksamer Geographieunterricht. Baltmannsweiler: Schneider Verlag Hohengehren.

Renkl, A., Gruber, H., Mandl, H., \& Hinkofer, L. (1994). Hilft Wissen bei der Identifikation und Steuerung eines komplexen ökonomischen Systems? Unterrichtswissenschaft, 22, 195-202.

Renkl, A. (2001). Träges Wissen. In D. H. Rost (Ed.), Handwörterbuch Pädagogische Psychologie (pp. 717-720). Weinheim: PVU.

Rhode-Jüchtern, T. (2013). Perspektivwechsel. In D. Böhn \& G. Obermeier (Eds.), Wörterbuch der Geographiedidaktik. Braunschweig, Deutschland: Bildungshaus Schulbuchverlage.

Schmidt, E. M. (2001). Mit Social Support vom Wissen zum Handeln - Die Wirkung "Kommunikativer Praxisbewältigung in Gruppen" (KOPING) auf den Lernprozess von Erwachsenenbildern. Aachen: Shaker.

Schraw, G. (2001). Promoting general metacognitive awareness. In H. J. Hartman (Ed.), Metacognition in learning and instruction. Theory, research and practice (pp. 3-16). Dordrecht: Kluwer. https://doi.org/10.1007/978-94-017-2243-8_1

Schreiner, C., Wiesner, C., Breit, S., Doppelstein, P., Heinrich, M., \& Steffens, U. (2019). Praxistransfer Schul- und Unterrichtsentwicklung. Münster, New York: Waxmann.

Seidel, T., \& Shavelson, R. J. (2007). Teaching effectiveness research in the past decade: The role of theory and research design in disentangling meta-analysis results. Review of Educational Research, 77(4), 454-499. https://doi.org/10.3102/0034654307310317

Schwarz-Govaers, R. (2005). Wissen und Handeln in der Berufsausbildung von Pflegekräften. In A. A. Huber (Ed.), Vom Wissen zum Handeln. Ansätze zur Überwindung der Theorie-Praxis-Kluft in Schule und Erwachsenenbildung (pp. 39-58). Tübingen: Verlag Ingeborg Huber.

Tiefel, S. (2004). Beratung und Reflexion. Eine qualitative Studie zu professionellem Beratungshandeln in der Moderne (Biographie und Profession. Studien zur qualitativen Bildungs-, Beratungs- und Sozialforschung. ZBBS-Buchreihe, $\quad B d$. 3). Wiesbaden: VS Verlag für Sozialwissenschaften. https://doi.org/10.1007/978-3-322-80921-6

Reich, K. (Ed.) (2003). Methodenpool. Retrieved from http://methodenpool.uni-koeln.de

Wenden, A. (1998). Metacognitive Knowledge and Language Learning. Applied Linguistics, 19(4), 515-537. https://doi.org/10.1093/applin/19.4.515

Wahl, D. (1991). Handeln unter Druck. Weinheim: Deutscher Studienverlag.

Wahl, D., Wölfing, W., Rapp, G., \& Heger, D. (1995). Erwachsenenbildung konkret: Mehrphasiges Dozententraining. Eine neue Form der erwachsenendidaktischen Ausbildung von Referenten und Dozenten. Weinheim: Deutscher Studien-Verlag.

Wahl, D. (2001). Nachhaltige Wege vom Wissen zum Handeln. Beiträge zur Lehrerbildung, 19, 157-174. urn:nbn:de:0111-pedocs-134531.

Wahl, D. (2006). Lernumgebungen erfolgreich gestalten. Vom trägen Wissen zum kompetenten Handeln (2nd ed.). Bad Heilbrunn: Klinkhardt.

Weiner, B. (1985). An Attributional Theory of Motivation and Emotion. Psychological Review, 92(4), 548-573. https://doi.org/10.1007/978-1-4612-4948-1_6

Weyland, U. (2010). Zur Intentionalität Schulpraktischer Studien im Kontext universitärer Lehrerausbildung (Wirtschaftspädagogisches Forum, Bd. 39). Paderborn: Eusl. 
Whitehead, A. N. (1929). The Aims of Education. New York: The Free Press.

Wittrock, M. C. (1986). Handbook of Research on Teaching (3rd ed.). New York: Macmillan.

Witzel, A. (1985). Das problemzentrierte Interview. In Jüttemann, G. (Ed.), Qualitative Forschung in der Psychologie. (pp. 227-255). Weinheim.

\section{Copyrights}

Copyright for this article is retained by the author(s), with first publication rights granted to the journal.

This is an open-access article distributed under the terms and conditions of the Creative Commons Attribution license (http://creativecommons.org/licenses/by/4.0/). 